\title{
PENGATURAN DAN SISTEM PENYELESAIAN TINDAK PIDANA PROSTITUSI ONLINE MENURUT HUKUM POSITIF
}

\author{
Herman \\ Sekolah Tinggi Ilmu Komputer (STIK) Handayani \\ Email: herman_ph@yahoo.co.id
}

\begin{abstract}
Positive legal arrangements on service users have not been effective in ensnaring and tackling online prostitution, as it does not in any way govern the users of services in an online prostitution crime. The system of settlement of criminal acts of online prostitution services pursuant to Number 11 of 2008 on Information and Electronic Transactions and Law Number 44 Year 2008 regarding Pornography does not specify the provisions on the users of online prostitution services specifically, so that these two laws can not entrap service users in the practice of online prostitution.
\end{abstract}

Keywords: Online prostitution, service users

\begin{abstract}
Abstrak
Pengaturan hukum positif terhadap pengguna jasa belum berlaku efektif dalam menjerat dan menanggulangi prostitusi online, karena sama sekali tidak mengatur mengenai pengguna jasa dalam tindak pidana prostitusi online. Sistem penyelesaian tindak pidana pengguna jasa prostitusi online berdasarkan Nomor 11 Tahun 2008 tentang Informasi dan Transaksi Elektronik dan Undang-undang Nomor 44 Tahun 2008 tentang Pornografi tidak menyebutkan ketentuan mengenai pengguna jasa prostitusi online secara khusus, sehingga kedua undang-undang inipun tidak dapat menjerat pengguna jasa dalam praktek prostitusi online.
\end{abstract}

Kata kunci : Prostitusi Online, pengguna jasa 


\section{PENDAHULUAN}

Tasyarakat biasanya mengetahui prostitusi ini dilakukan di sebuah daerah atau tempat, baik itu di pinggir jalan, pinggir rel, lokalisasi menunggu pelanggan pengguna jasanya datang. Dengan adanya perkembangan
manan tempan lainnya dengan cara pelaku menjajakan dirinya dan ilmu pengetahuan dan teknologi sekarang ini serta pengaruh globalisasi cara-cara yang dilakukan dalam bertransaksi sudah bermacam-macam, tidak lagi dengan saling bertemu di tempat-tempat yang biasa menjajakan diri. Menggunakan media internet adalah salah satunya.

Prostitusi merupakan masalah yang tidak hanya melibatkan pelacurnya saja, tetapi lebih dari itu yaitu merupakan suatu kegiatan yang melibatkan banyak orang seperti germo, para calo, serta pengguna jasa yang sebagian besar pelakunya merupakan laki-laki yang sering luput dari perhatian aparat penegak hukum. Dalam ketentuan hukum positif yang ada di Indonesia hanya melarang mereka yang membantu dan menyediakan pelayanan seks secara illegal, artinya larangan hanya diberikan untuk mucikari atau germo, para calo, dan pelacur sedangkan pengguna jasa seks komersial sendiri sama sekali tidak ada pasal yang mengaturnya.

Dalam pelaksanaannya, penanggulangan prostitusi lebih banyak dilakukan dengan menertibkan dan menangkap perempuan pelacur yang dilakukan oleh aparat penegak hukum, sedangkan laki-laki para pelanggan atau pengguna jasa seks komersialnya jarang dan bahkan tidak pernah ditangkap atau luput dari perhatian aparat penegak hukum. Cara penertiban seperti ini menunjukkan adanya ketidakadilan gender, karena terdapat diskriminasi terhadap perempuan. Adanya ketidakadilan gender dapat menyebabkan sulitnya penanggulangan prostitusi, karena pelacur merupakan paradigma interaksi antara perempuan dan laki-laki diluar perkawinan. Dalam interaksi tersebut perempuan diibaratkan sebagai pihak yang disewa, sedangkan laki-laki (pengguna jasa) sebagai pihak penyewa.

Salah satu bentuk kejahatan yang akhir-akhir ini sedang marak dan mengkhawatirkan orang banyak adalah prostitusi online. Dimana dalam prostitusi online tersebut melibatkan beberapa pihak antara lain penyedia jasa, pengguna jasa dan pekerja seks komersial (PSK). Meskipun pada dasarnya bentuk kejahatan ini telah diatur dalam undang-undang nomor 11 tahun 2008 tentang informasi dan traksaksi elektronik, namun hal itu kurang maksimal disebabkan karena mudahnya akses internet serta penegakan hukum yang kurang efektif karena dengan gampangnya akses menuju dunia teknologi informatika maka kejahatan cybercrime tentu dengan mudahnya dilakukan, salah satunya adalah prostitusi online. 
Berkaitan dengan permasalahan diatas, maka penulis bermaksud meninjau permasalahan mengenai pengaturan dan sistem penyelesaian tindak pidana prostitusi online menurut hukum positif.

\section{PEMBAHASAN}

\section{A. Pengaturan Tindak Pidana Pengguna Jasa Prostitusi Online}

Hukum positif yang mengatur mengenai prostitusi online yaitu KUHP, Undang-undang No. 11 tahun 2008 tentang Informasi dan Transaksi Elektronik dan Undang-undang No. 44 tahun 2008 tentang Pornografi. Pemidanaan yang diatur dalam Undang-undang tersebut diatas menjelaskan mengenai pemidanaan terhadap penyedia layanan saja. Undang-undang tersebut tidak mengatur ketentuan pemidanaan bagi pengguna jasa dalam tindak pidana prostitusi online.

Melihat dari berbagai penjelasan pasal dalam KUHP, Undang-undang No. 11 tahun 2008 tentang Informasi dan Transaksi Elektronik dan No. 44 tahun 2008 tentang Pornografi belum berlaku efektif dalam menjerat dan menanggulangi bisnis prostitusi online, sama sekali tidak mengatur mengenai pengguna jasa dalam prostitusi online, sehingga pengguna jasa prostitusi itu sendiri tidak dapat dijerat berdasarkan Hukum Positif yang ada di Indonesia. Seharusnya secara khusus dalam Undang-undang No. 11 tahun 2008 tentang Informasi dan Transaksi Elektronik dan No. 44 tahun 2008 tentang Pornografi dapat menjerat subyek prostitusi itu secara keseluruhan.

\section{B. Sistem Penyelesaian Tindak Pidana Pengguna Jasa Prostitusi Online}

1. Menurut Kitab Undang-undang Hukum Pidana

Melihat pasal-pasal yang ada dalam Kitab Undang-undang Hukum Pidana, tidak ada pasal yang dapat digunakan untuk menjerat pengguna jasa seks komersial maupun pekerja seks komersial itu sendiri. Apabila kita lihat pasal 296 dan pasal 506 Kitab Undang-undang Hukum Pidana tidak ditujukan kepada pengguna jasa seks komersial maupun pekerja seks komersial, akan tetapi ditujukan kepada germo dan calo seks komersial saja. Pasal 281 Kitab Undang-undang Hukum Pidana sangat sulit untuk diterapkan kepada pengguna jasa seks komersial, karena dalam kenyataanya pengguna jasa seks komersial melakukan hubungan kelamin dengan secara tertutup. Pasal 284 Kitab Undang-undang Hukum Pidana masih bersifat diskriminatif, karena ancaman dapat diberlakukan kepada perempuan yang melakukan perbuatan zina baik yang bersuami ataupun 
yang tidak bersuami dapat dipidanakan, sementara ketentuan untuk lakilaki yang belum beristri tidak dapat dikenakan pidana.

Kitab Undang-undang Hukum Pidana sekarang ini memang sudah layaknya direvisi, karena dengan merevisi Kitab Undang-undang Hukum Pidana berarti memperkuat dan memperjelas segala tindakan yang bersifat kesusilaan.

2. Menurut Undang-Undang Nomor 11 Tahun 2008 Tentang Informasi dan Transaksi Elektronik

Undang-Undang Nomor 11 Tahun 2008 Tentang Informasi dan Transaksi Elektronik (UU ITE) tidak menyebutkan kata prostitusi dalam semua pasalnya. Kecuali dalam pasal 27 yang berisikan tentang perbuatanperbuatan yang dilarang, menyebutkan kata kesusilaan yang menyangkut kepada hal-hal yang berbau pornografi.

Pasal 27 ayat (1) mengenai prostitusi online diancam dengan pidana penjara maksimal 6 tahun dan/atau denda maksimal 1 miliar rupiah. Dalam Undang-undang ini tidak dijelaskan mengenai sanksi pidana bagi para pengguna jasa dalam tindak pidana prostitusi online. Undang-undang inipun tidak dapat menjerat pelaku pengguna jasa layanan seks komersial prostitusi online, sehingga Undang-undang inipun tidaklah tepat digunakan untuk menanggulangi permasalahan prostitusi yang kompleks. Seharusnya Undang-undang ini mengatur sanksi pidana untuk seluruh subyek dalam tindak pidana prostitusi online, karena pengguna jasa layanan seks komersial prostitusi online adalah bagian dari subyek tindak pidana prostitusi dan pengguna jasa layanan seks komersial prostitusi online melibatkan transaksi elektronik dalam melakukan kegiatan prostitusinya.

3. Menurut Undang-Undang Nomor 44 Tahun 2008 Tentang Pornografi

Undang-undang Nomor 44 Tahun 2008 tentang Pornografi yang diharapkan mampu membatasi materi seksualitas dalam tindak pidana prostitusi online tidak dapat menjerat pengguna jasa prostitusi online, undang-undang ini hanya membatasi pihak-pihak yang dapat dikenakan sanksi yaitu Sanksi bagi pelaku penyedia jasa terdapat dalam pasal 30, sanksi bagi pemilik server terdapat dalam pasal 33, sanksi bagi pekerja seks komersial terdapat dalam pasal 34, dan sanksi bagi mucikari terdapat dalam pasal 35.

Setelah melihat penjelasan Undang-undang Nomor 44 tahun 2008 tentang Pornografi sama sekali tidak menjelaskan mengenai pengguna jasa prostitusi online secara khusus, sehingga dalam hal ini Undang-undang tersebut tidak dapat menjerat pengguna jasa dalam praktek prostitusi online. 
Hal itu dikarenakan pembuat kebijakan sepertinya tidak duduk bersama para ahli yang benar-benar mengerti tentang pembahasan undang-undang tersebut. Seharusnya diharapkan Undang-undang tersebut dapat menjerat subyek dalam prostitusi online secara keseluruhan, agar terciptanya suatu keadilan dan kepastian hukum.

4. Menurut Hukum Islam

Prostitusi telah membuat kerusakan di muka bumi dan membuat kerusakan bagi orang lain, jelas dilarang dalam Al-Quran dan Hadist, pengutamaan dihindarinya mafsadat daripada menarik keuntungan yang sesuai dengan maqasid as-syari'ah. Jika manusia melanggar perintah ataupun larangan Allah, berarti dia telah melakukan perbuatan tercela, dan dianggap telah melakukan tindakan kriminal, sehingga harus dijatuhi hukuman atas kriminalitas yang dilakukannya. Sebab, tanpa pemberlakuan hukuman bagi para pelanggar, hukum tidak akan memiliki arti apa-apa. Suatu perintah tidak akan bernilai apa-apa jika tak ada balasan (hukuman) bagi pelanggar yang mengabaikan perintah tersebut. Maka sudah seharusnyalah pelaku atau pemilik website hal lainnya yang menyangkut prostitusi online tersebut dijatuhkan sanksi sesuai dengan ketentuan hukum Islam. Kalau tindak pidana zina yang menjadi ujung kegiatan prostitusi ini Islam mengaturnya dalam firman-firman Allah SWT dengan sangat jelas.

5. Menurut Peraturan Daerah DKI Jakarta Nomor 8 Tahun 2007 Tentang Ketertiban Umum

Muatan yang terdapat pada Peraturan Daerah DKI Jakarta Nomor 8 Tahun 2007 tentang Ketertiban Umum sebagaimana diatur dalam Pasal 42 ayat (2) yaitu :

"Setiap orang dilarang : a. menjadi penjaja seks komersial; b. menyuruh, memfasilitasi, membujuk, memaksa orang lain untuk menjadi penjaja seks komersial; c. memakai jasa penjaja seks komersial".

Dalam hal pengguna jasa prostitusi online sebenarnya akan dapat mengungkap dan menjerat siapa saja yang menjadi pengguna jasa prostitusi online, dengan ketentuan jika transaksi antara pengguna jasa dengan penyedia jasa layanan prostitusi online itu dilakukan dengan cara mentransfer sejumlah uang kerekening pihak yang menyediakan jasa prostitusi online. Mengingat prostitusi adalah suatu tindak pidana yang masalahnya begitu kompleks perlu ada kerjasama yang sinergi antar wilayah yang menjadi pengirim serta wilayah penerima/penyalur, sehingga bisa dilakukan upaya pencegahan atau pemulihan/penanggulangan. 
Memang tidak penting mencari siapa yang salah atau yang benar dalam hal ini. Yang terpenting dalam penanggulangan prostitusi adalah bagaimana pemerintah menggunakan cara berfikir yang lebih adil dan tidak hanya merugikan salah satu pihak.

Sampai saat ini memang belum ada undang-undang yang pas dan ampuh untuk menyelesaikan masalah prostitusi secara utuh dan tegas. Namun jika dibandingkan dengan hukum positif yang berlaku di Indonesia secara umum, tentunya Perda DKI Jakarta Nomor 8 Tahun 2007 tentang Ketertiban Umum ini merupakan peraturan yang paling tepat dalam menjerat pengguna jasa prostitusi online. Karena peraturan ini hanya mengatur secara khusus (lex spesialis) terhadap daerah tertentu yang tidak bisa dterapkan didaerah lain masih memberikan celah kepada pengguna jasa prostitusi online diluar Propinsi DKI Jakarta dalam melakukan kegiatannya.

\section{PENUTUP}

Pengaturan tindak pidana terhadap pengguna jasa prostitusi online menurut hukum positif di Indonesia belum berlaku efektif dalam menjerat dan menanggulangi bisnis prostitusi online, karena sama sekali tidak mengatur mengenai pengguna jasa dalam prostitusi online, sehingga pengguna jasa prostitusi itu sendiri tidak dapat dijerat berdasarkan hukum positif yang ada di Indonesia.

Adapun saran penulis yaitu seharusnya pengguna jasa dalam tindak pidana prostitusi online juga diatur dalam hukum positif yang ada di Indonesia, mengatur seluruh subyek yang berhubungan dengan tindak pidana prostitusi online merevisi atau membentuk undang-undang baru mengenai prostitusi. 


\section{DAFTAR PUSTAKA}

Abdulkadir, Muhammad, 2004, Hukum dan Penelitian Hukum, Bandung : PT Citra Adiya Bakti.

Abdul Wahid dan M. Labib, 2005, Kejahaan Mayantara (cyber crime), Bandung: Refika Aditama.

Adam, AS, 1969, Tinjaun tentang zinah dalam rangka delik susila pada KUHP, Jakarta : Swada.

Agus Raharjo, 2002, Cyber Crime: Pemahaman dan Upaya Pencegahan Kejahatan Berteknologi, PT citra Aditya Bakti, Bandung.

Ahmad, Muslich Wardi, 2005, Hukum Pidana Islam, Jakarta: Sinar Grafika.

Sholehuddin, 2002, Sistem Sanksi Dalam Hukum Pidana, Kota besar: Raja Grafindo Persada.

Tanjung, Armaidi, dan Delfita, Elfi, 2001,Mengapa Zina dilarang, Solo: CV Pustaka Mantiq,.

Widodo, 2009, Sistem Pemidanaan Dalam Cyber Crime, Laksbang Mediatama.

Wiryono Prodjodikoro, 1986, Tindakan-Tindakan pidana Tertentu di Indonesia, Bandung: Erosco.

Zahrah, Muhammad Abu, 2003, Ushul Fiqih, alih bahasa Saefullah Ma'sum dkk., Jakarta: Pustaka Firdaus.

Zein, Satria Efendi M., 2005, Ushul Fiqh, Jakarta: Kencana.

\section{Peraturan Perundang-undangan}

Kitab Undang-undang Hukum Pidana (KUHP)

Undang-undang No.11 tahun 2008 tentang Informasi dan Transaksi Elektronik.

Undang-undang No. 44 tahun 2008 tentang Pornografi

Peraturan Daerah DKI Jakarta Nomor 8 Tahun 2007 tentang Ketertiban Umum 